\title{
CONCURSO DE MONOGRÁFIAS
}

A «Revista do Serviço Público», com o propósito de dar maior incentivo ao estudo cos problemas de Administração Pública Brasileira, tem a satisfação de transcrever, na integra, a Portaria n. ${ }^{\circ} 281$, de 1959, com a qual, o Diretor-Geral do D.A.S.P. resolve aprovar as Instruções Reguladoras do Concurso de Monografia, criado pelo Serviço de Documentação e a ser realizado pela $\mathrm{Re}$ vista do Serviço Público, em comemoração altamente significativa do $\ll$ Dia do Servidor Público», em outubro do corrente ano.

Maior amplitude e prestígio a esta iniciativa dependerá, naturalmente, da qualidade e extensão dos trabalhos concorrentes aos prêmios previstos nas Instruções abaixo.

\section{PORTARIA DE 6 DE JULHO DE 1959}

O Diretor Geral do Departamento Administrativo do Serviço Público, atendendo à proposta do Serviço de Documentação do mesmo Departamento, resolve:

N. 281 - Aprovar as instruções destiradas a regular o concurso de monografias sôbre Froblemas de Administração Pública Federal, que será realizado, em 1959, pela Revista do Serviço Público.

Instrutções a que se refere a Portaria n. 281 , de 6 de julho de 1959

Institue na Revista do Serviço Público concurso destinado a premiar os melhores trabalhos técnico-administrativos que forem apresentados na forma abaixo indicada.

\section{$I$ - DOS CONCORRENTES}

1. Poderão concorrer aos prêmios do presente concurso os estudantes de escolas de administração, direitó ou economia e todos os servidores públicos federais, sediados ou não no Distrito Federal, exceto os em exercício na Revista do Serviço Público e os membros da Comissão de Classificação e Julgamento.

2. Os temas dos trabalhos versarão sôbre qualquer assunto de administração federal de interêsse nacional.
3. Os trabalhos deverão ser inéditos e enviados em três (3) cópias sem ultrapassar o limite de 30 páginas datilografadas ou mimeografadas em espaço $2 \mathrm{em}$ papel ofício, até o dia 28 de outubro do corrente ano, $\mathrm{Dia}$ do Servidor Público, diretamente à Revista do Serviço Público (Palácio do Ministério da Fazenda, 6. ${ }^{\circ}$ andar, sala 621 - DF), ou por via postal, sob registro.

4. Considera-se inscrito o trabalho que, sob registro, fôr pôsto no correio até o dia 28 de outubro do ano em curso, inclusive.

5. Cada candidato só poderá concorrer aos prêmios previstos nestas Instruções com um trabalho apenas.

6. Cada trabalho, obrigatòriamente firmado por pseudônimo, deverá ser acompanhado de sobrecarta fechada e rubricado, com uma cédula de identificação do candidato, na qual serão mencionados o pseudônimo usado, o nome verdadeiro, data de nascimento, enderêço, cargo ou função, número de matrícula e repartição a que serve, ou curso e escola onde se acha matriculado como aluno regular.

$$
\text { II - DOS PRÊMIOS }
$$

1. Haverá 3 (três) prêmios destinados aos trabalhos de melhor qualidade, classificados em $10^{\circ}, 2 .^{\circ}$ e $3 .^{\circ}$ lugares respectivamente: $\mathrm{Cr} \$ 15.000,00$ (quinze mil cruzeiros), $\mathrm{Cr} \$$ $10.000,00$ (dez mil cruzeiros) e $\mathrm{Cr} \$ \ldots \ldots$. $5.000,00$ (cinco mil cruzeiros).

2. Além dos três prêmios acima haverá o prêmio secundário de civulgação na Revista do Serviço Público dos trabalhos premiados e de outros que a Comissão julgar dignos de divulgação.

\section{- III - DA ADMinistraÇão do CONCURSO}

1. Será constituida uma Comissão Julgadora de três membros designados pelo Diretor Geral do D.A.S.P. para a escolha dos originais merecedores dos prêmios.

2. O Presidente da Comissão Julgadora designará um dos seus membros para coordenar os trabalhos, distribuir os originais pelos demais membros e apresentar relatório geral. 
3. Caberá ao membro coordenador, entre outras providências, verificar se os trabalhos satisfazem as condições estabelecidas nestas instruçôes.

$$
\text { IV - DO JULGAMENTO }
$$

1. Será desclassificado, de plano, o trabatho que não se conformar com as exigências destas instruções, ou contiver graves erros de linguagem.

2. Do parecer sôbre os trabalhos examinados deverão constar a justificativa do julgamento e a ordem de classificação.

3. Até 90 (noventa) dias após a data de encerramento das inscrições, a Comissão
Julgadora apresentará ao Diretor Geral do D.A.S.P. o resultado do julgamento realizado, acompanhado de relatório devidamente autenticado por todos os seus membros.

4. A cerimônia de abertura das sobrecartas, com a identificação dos candidatos vitoriosos, será pública.

5. Não serão devolvidas aos candidatos as cópias dos trabalhos apresentados.

6. Os casos omissos serão resolvidos pela Comissão Julgadora.

Manoel Caetano Bandeira de Mello, Diretor do Serviço de Documentação. 